\title{
Theoretical Lessons from EMU and Banking Union: Plus ça change
}

\section{David Howarth and Lucia Quaglia}

This is an authors' pre-print version. Please reference as:

Howarth, David and Quaglia, L. (2020) 'Theoretical Lessons from EMU and Banking Union: Plus ça change', in Howarth, D. and Schild, J., eds., The Difficult

Construction of European Banking Union, London: Routledge, pp. 38-50.

\begin{abstract}
:
Why did Euro Area member state governments decide to move to Banking Union (BU) - presented by proponents as a crucial move to 'complete' Economic and Monetary Union (EMU) - only in 2012, over twenty years after the adoption of the Maastricht Treaty? Why has a certain design for BU been chosen and some elements of this design prioritised over others? This paper interrogates previous academic accounts on the move to and the design of EMU - neofunctionalist, intergovernmentalist and constructivist - evaluating their explanatory power with reference to BU. It is argued that the asymmetrical design of EMU generated a variety of spill-overs and, hence, a neofunctionalist drive to supranationalise control over bank supervision and financial support for banks as part of the so-called 'completion' of EMU. However, intergovernmental negotiations informed by moral hazard and domestic political economy concerns explain the asymmetrical design of BU agreed by national governments.
\end{abstract}

Keywords: European Integration Theory, Economic and Monetary Union (EMU), Banking Union (BU), Single Supervisory Mechanism (SSM), Single Resolution Mechanism (SRM), European Stability Mechanism (ESM)

\section{Introduction}

In June 2012, the European Council and Euro Area summit agreed to complete Economic and Monetary Union (EMU) through the creation of 'Banking Union' (BU), which was to be based on four components: a single framework for banking supervision; a single framework for banking resolution; a common deposit guarantee scheme; and a common backstop for temporary financial support. In October 2013, the Council of Ministers approved the Regulation for the establishment of a Single Supervisory Mechanism (SSM). In July 2014, the Council of the European Union and the European Parliament approved the Regulation for the setting up of the Single 
Resolution Mechanism (SRM) with the Single Resolution Board (SRB). The third and fourth elements - the planned European Deposit Insurance Scheme (EDIS) and the common backstop for temporary financial support — escaped agreement. The European Stability Mechanism (ESM) was established by the Euro Area member states in September 2012 to replace the temporary European Financial Stability Facility (EFSF). The Commission, the European Central Bank (ECB) and a number of member states wanted the ESM to provide financial support to ailing banks and to the SRM both in the context of fund mutualisation and beyond, but - the emergency recapitalisation of Spanish banks aside - there remains no agreement on the role of the ESM in BU to date and the mechanism remains an intergovernmental body outside the EU institutional framework.

The proposals for $\mathrm{BU}$ amount to a radical initiative to stabilise the national banking systems exposed directly to the sovereign debt crisis. BU was also intended to reverse the fragmentation of European financial markets caused in large part by the crises. BU implied a significant transfer of powers from the national to the supranational level. Hence, the decision to create BU represented a major development in European economic governance and European integration history more generally. Why was BU — presented by proponents as a crucial move to 'complete' EMU — proposed in 2012, over twenty years after the adoption of the Maastricht Treaty? Why has a certain design for $\mathrm{BU}$ been chosen and some elements of this design prioritised over others? In order to answer these questions, this paper examines previous scholarly accounts and the theories that they apply to explain the move to and the design of EMU, evaluating their explanatory power in the case of BU. It is argued that an incomplete EMU generated a variety of spill-overs and a neofunctionalist dynamic 
encouraging initiatives to 'complete' EMU. However, intergovernmental negotiations informed by both ideas and domestic political economy interests explain how an agreement was reached on BU and why a specific — in large part, but not entirely, German-directed - design for BU was agreed. We also argue that member state preferences and intergovernmental dynamics that shaped the making of EMU find their parallel in the making of BU.

This paper is structured as follows. Section 2 reviews the main theoretical approaches to the politics and political economy of the creation of EMU. It is argued that spillovers from the Single Market and from previous monetary integration, as well as a pro-active Commission, were the main drivers towards EMU. The ideational power of a price stability-oriented economic paradigm, and the structural / bargaining power of Germany largely accounts for the incompleteness of EMU and its asymmetric design. Section 3 assesses the extent to which the explanations put forward with reference to the establishment and design of EMU have analytical leverage with reference to the move towards BU and the design eventually agreed. It is argued that spill-overs from an incomplete EMU, as well as a pro-active ECB, were the main drivers towards BU. The structural / bargaining power of Germany and its preferences shaped by moral hazard concerns and domestic political economy considerations largely account for the incompleteness of BU and its asymmetric design. The penultimate section and conclusion compare the main explanations on the making of EMU and BU, consider their relative explanatory merit, and tease out some lessons for European economic governance.

\section{Explaining the making of EMU}


A number of theoretical approaches in European integration studies, political science and political economy have been applied to explain the decision to move to EMU and the design of the EMU project, notably, versions of neofunctionalism, constructivism and intergovernmentalism (see Verdun 2002; Sadeh and Verdun 2009). Moreover, a number of political economy approaches have been applied to investigate the preferences of EU member states on the main components of EMU - namely, monetary policy, exchange rate policy, and fiscal policy — as well as the 'winners' and 'losers' from EMU.

A neofunctionalist or supranational governance approach understands the move to EMU as the result of spill-overs from previous market integration and monetary integration (see, for example, Sandholtz 1998; Jabko 1999). A major prior development was the establishment of the European Monetary System (EMS), and specifically the Exchange Rate Mechanism (ERM) in 1979, which set in place a system of semi-fixed exchange rates among the participating countries. Furthermore, EU supranational authorities, above all Jacques Delors and a number of European Commission officials, played a strategic role in driving the project forward (see Jabko 1999), by acting as policy entrepreneurs with the - either active or passive support of many of Europe's largest manufacturing companies. Economic spill-overs formed the core element of the official justification wielded by the European Commission to explain the need for EMU. The Commission and a number of federalist-minded economic policy officials in the member states and academic economists insisted that the gains of the Single Market could only be optimized with a single currency: notably in the influential publication 'One Market, One Money' (Commission 1990). Following a similar reasoning, one euro-federalist Bank of Italy 
official, Tommaso Padoa-Schioppa (1982), built on the Mundell-Fleming 'unholy trinity' of fixed exchange rates, full capital mobility and national monetary policies, by adding the Single Market — thus transforming the trinity into an 'inconsistent quartet' in the European Community (EC) context. As with the Commission, a number of economists also stressed the instability of the ERM of the EMS especially given currency speculation - and the functional need to move from the ERM's semi-fixed exchange rates to EMU (Giavazzi et al. 1989; De Grauwe 1990). On the one hand, these functionalist dynamics contribute to explaining the rationale for EMU. On the other hand, they do not shed light on the EMU design agreed by the member states in the early 1990s. On this we must turn to ideas and intergovernmental dynamics.

A second approach that has been used to explain the move to and the design of EMU is constructivism (McNamara 1998; Marcussen 2000; Verdun 1999). There are several variations of constructivism, but what they all have in common is the explanatory power assigned to ideas, defined as a set of causal beliefs concerning a certain policy area, rather than material (mostly, economic) interests. Ideas-based constructivist accounts contrast with the interests-based approach of intergovernmentalist explanations. Thus, constructivist approaches emphasize the importance of socialisation in international or European fora as a mechanism that facilitated ideational convergence towards EMU. Alternatively, they focus on the instrumental role of ideas as, for example, 'policy narratives'. Some ideational approaches to the move to and design of EMU have focused on the role of central bankers as an epistemic community supporting a stability-oriented design for EMU, based on central bank independence and anti-inflationary goals (Verdun 1999; 
Marcussen 2000). Other works have considered a broader set of actors, not only central bankers, in the ideational convergence towards EMU. McNamara (1998) has traced the 'currency of ideas', that is the spread of the stability-oriented macroeconomic paradigm from Germany to other member states. Thus, ideational convergence among macroeconomic elites across the EU explains why it was possible to reach an agreement on EMU, as well as the specific 'sound money' and 'sound public finance' (Dyson 2000) design chosen for EMU. Finally, other works have applied a 'strategic constructivism' (Jabko 1999) by examining the instrumental use of ideas by the European Commission in order to promote EMU.

The vast majority of research investigating the move to and the design of EMU has adopted an intergovernmentalist approach (Kaltenthaler 1998; Moravcsik 1998; Dyson and Featherstone 1999; Loedel 1999; Howarth 2001). There are several versions of intergovernmentalism; their common denominator is the focus on national interests and the decision-making power of national governments negotiating in intergovernmental fora. Intergovernmentalist accounts of EMU have investigated the (often competing) interests of the member states that were reconciled in the context of EU-level negotiations, which often resulted in convoluted compromises. Intergovernmentalist accounts have also considered the different bargaining power of the member states, focusing principally on the main member states, notably Germany and, to a lesser extent, France.

In the asymmetric ERM / EMS, the German currency (the deutsche mark) was the 'anchor' of the mechanism and the German central bank (the Bundesbank) could freely set its monetary policy objectives. The other participating countries had to 
'adjust' their monetary policy by following the decisions of the Bundesbank (Kaltenthaler 1998; Loedel 1999). According to intergovernmentalist explanations, the establishment of EMU was a way for 'follower countries' (especially, France and Italy) to end the German dominance of the ERM. In EMU, the policy-makers of these countries would have a say in the making of a single monetary policy and have a seat at the ECB (Moravcsik 1998; Howarth 2001). The German government had, it can be argued, a 'constrained veto' power in the context of the negotiations leading to the Maastricht Treaty (Bulmer and Paterson 2013). The status quo - the maintenance of the asymmetric ERM — was politically impossible given French and other member states reform demands. However, the adoption of reforms necessary to transform the ERM into a more symmetrical — less German dominated - mechanism was politically and economically unacceptable to most of the German economic policy making elite, notably the Bundesbank (Dyson and Featherstone 1999). The German government was thus 'constrained' in its policy options. The move to Monetary Union was accepted by Chancellor Helmut Kohl for principally 'European' political reasons - despite intense opposition from within the German government, the Bundesbank and a significant majority of the German public (Dyson and Featherstone 1999). However, German policy-makers imposed most of the EMU design, centred on an independent ECB, independent national central banks and stability-oriented macroeconomic policies.

Some intergovernmentalist studies have examined in more detail the domestic political economy of EMU in the main member states (Frieden 1996; Oatley 1997; Walsh 2000), teasing out the main 'winners' and 'losers' from EMU among national economic and socio-economic interests, and hence identifying the main supporters of 
and opponents to the project. By focusing on the preferences of domestic interest groups regarding the main components of EMU (monetary policy, fiscal policy and exchange rate policy), these studies have uncovered the social bases underpinning (or in certain cases, undermining) EMU, complementing the elite-focused account of the intergovernmentalist approaches summarised above.

By combining the main theoretical approaches discussed above, one obtains a multifaceted picture of the making of EMU — what Dyson and Featherstone (1999) call a 'multi-dimensional chess game'. The main driving forces in the process of European monetary integration were functional dynamics resulting from increasing economic and monetary interdependence in Europe; the entrepreneurship of supranational actors, notably in the Commission, and its president Jacques Delors; and the mobilisation of policy-makers in those member states that followed Germany's monetary policy in the EMS, and regarded EMU as an institutional mechanism to pool monetary policy making power, rather than de facto ceding it to the Bundesbank. However, member states were internally divided on EMU, the establishment of which would generate winners and losers at the domestic level. The main obstacles to be overcome in the construction of EMU were the reluctance of German policy-makers, which had considerable bargaining power because of the economic size of their country and because Germany was the 'hegemon' in the EMS. Consequently, German policy-makers were very influential in shaping the institutional design of EMU. In addition to material interests, ideas were also important in the making of EMU, facilitating an agreement among national economic policy-making elites and in promoting the German-inspired stability-oriented economic paradigm at the core of the EMU project. 
Eventually, the institutional design of EMU agreed in Maastricht was asymmetric, whereby full monetary union was not coupled with full economic union (Dyson 2000; Hodson 2009). Fiscal Union was notably missing and had deliberately been left out, principally (but not exclusively) because of the opposition of German policy-makers (Dyson and Featherstone 1999), and despite the half-hearted calls of French policymakers for gouvernement économique (Howarth 2001). Moreover, there was some debate as to whether the ECB should be responsible (or not) for banking supervision in the Euro Area. Due to the opposition of German and French policy-makers, among others, prudential supervision remained at the national level (Dyson and Featherstone 1999). On several issues, compromises among the member states were needed in order to move the project forward. For example, the initial formulation of the convergence criteria to determine the member states allowed to join the third and final stage of EMU was softened during the negotiations on the Maastricht Treaty.

\section{Explaining the making of Banking Union}

Mirroring the theoretical debate on the making of EMU, a number of theoretical approaches can be applied to the making of BU. A neo-functionalist approach would argue that BU was a spill-over from the incomplete EMU, which, combined with a supranational governance approach, stresses the importance of supranational institutions, notably, the Commission and, especially, the ECB in promoting BU. Indeed, several neofunctionalist works have explained shifts in member state preferences on Banking Union due to spill-overs from previous economic integration (see, for example, Niemann and Ioannou 2015; Epstein and Rhodes 2016), and/or have emphasised the pace-setting roles of the ECB and the European Commission (De 
Rynck 2015; Epstein and Rhodes 2016; Verdun 2017), as well as the 'collaborative leadership' between intergovernmental and supranational institutions, especially the Presidency of the European Council and the Commission (Nielsen and Smeets 2018). Some institutionalist studies have also stressed the path-dependence created by the 'incompleteness' (or 'asymmetry') of EMU (Verdun 2015) and by previous ‘differentiated integration’ related to EMU (Schimmelfennig 2016).

The thrust of the neofunctionalist approach is that BU was the result of spill-overs from previous integration, first and foremost, EMU and the Single Market in finance. The establishment of EMU supranationalised monetary policy, but left banking supervision and resolution at the national level, thanks to the opposition of a number of member state governments — including the German and French — during the negotiations preceding agreement on the Maastricht Treaty (Dyson and Featherstone 1999). Moreover, the function of lender of last resort (LLR) for banks, which was previously performed by national central banks, was only implicitly transferred to the ECB, which, on this issue, maintained a 'constructive ambiguity' (Chang 2018).

The sovereign debt crisis can be understood, in part, as a negative spill-over from an incomplete EMU (Howarth and Quaglia 2015). The international financial crisis that reached its peak in the autumn of 2008 can be seen as an external asymmetric shock which hit Euro Area member states in very different ways, and a good number with considerable force. At different stages of the crisis, Ireland and Spain were hit particularly hard, banks suffered major losses and needed considerable financial assistance. In both cases, the state lacked sufficient funds and had to resort to external financial assistance from the EU / Euro Area and the International Monetary Fund 
(IMF). In both cases, fragile banks held worryingly large quantities of home government debt. Hence, in Ireland and Spain the banking crisis became a sovereign debt crisis. In Greece, persistent fiscal imbalances were at the root of its sovereign debt crisis and the need for external financial assistance. Moreover, macroeconomic imbalances in Spain and Greece were fuelled by capital inflows intermediated by banks, which national policy-makers had been unable (and somewhat unwilling) to control (Hall 2014; Matthijs 2016b).

The limited integration of European financial services markets (and, notably, banking markets), even after more than a decade of EMU, remained a major weakness in the Single Market. The global financial crisis first and the sovereign debt crisis later fragmented the single financial market: banks reduced their cross-border activities and variation in the cost of money (i.e., the interest rate paid on bank loans) increased considerably across a number of Euro Area member states. In turn, this variation disrupted the conduct of the ECB's monetary policy. The move to establish BU was a direct response to market fragmentation and thus should be seen as much in terms of reinforcing the Single Market as stabilizing banks and EMU (Howarth and Quaglia 2016).

As the operation of the ERM had demonstrated in bold relief the Mundell-Fleming trilemma for participating member states, an incomplete EMU intensified the 'financial trilemma' for Euro Area member states. Dirk Schoenmaker's 'financial trilemma' (2013) examines the interplay of financial stability, international banking and national financial policies, arguing that any two of the three objectives can be 
combined but not all three: one has to give. ${ }^{1}$ The establishment of EMU made the financial trilemma more acute and ultimately untenable in the Euro Area. The introduction of the euro and the Financial Services Action Plan substantially increased financial integration in the EU — especially cross border banking in the Euro Area but banking supervision and resolution remained at the national level. Furthermore, the function of lender of last resort for banks and sovereigns could no longer be performed at the national level by the central bank in the Euro Area, and national governments (fiscal authorities) were constrained by fiscal rules. The international financial crisis was an external shock to financial stability in the Euro Area, but the member states no longer had all the instruments to deal effectively with crisis at the national level, nor had these instruments been set up at the EU / Euro Area level.

Consequently, the safeguard of financial stability — or the effective minimisation of financial instability - could only be achieved effectively at the Euro Area level. For these reasons, Euro Area member state governments agreed (in some cases with great reluctance) to move to BU. BU was to replace the third element of Schoenmaker's trilemma. These national financial policies include regulation, which, even prior to BU was largely set at the EU level; supervision, which for large systemically important banks was to be transferred to the European Central Bank (ECB) / SSM in $\mathrm{BU}$; resolution, which was to be performed by the SRM in BU; accompanied by the creation of the EDIS and the use of the ESM as a common fiscal backstop. BU was supposed to address the institutional shortcoming highlighted in Schoenmaker's

\footnotetext{
${ }^{1}$ Schoenmaker's financial trilemma is problematically conceived in that financial stability can never be assured. Rather, the conditions that optimise the likelihood of stability — or, more precisely, minimise the likelihood of excessive instability — can be established (Howarth and Quaglia 2016).
} 
trilemma by transferring these policies from the national level to the Euro Area (to be precise, BU) level (Howarth and Quaglia 2016).

The ECB was the main supranational institution involved in the making of BU (Epstein and Rhodes 2016; De Rynck 2015), thus assuming in part the policy entrepreneurship performed by the Commission in the making of EMU. Prior to the debate on BU, some senior ECB officials (for example, Tommaso Padoa-Schioppa) had expressed support for the ECB to take over supervisory functions (Howarth and Loedel 2005). However, this was not official ECB policy. Carstensen and Schmidt (2017) argue that supranational actors, notably the ECB and to a lesser extent the Commission, were able to exert 'institutional and ideational power' in the second stage of the sovereign debt crisis (i.e., from 2012 onwards), which led to the establishment of BU. The ECB was a keen supporter of the SSM and SRM, calling for a wide scope of application and centralised competences. On several occasions, the ECB President reiterated that these mechanisms should not be 'single' only in name (ECB 2012). The ECB contributed forcefully to the BU debate and was able (and willing) to act decisively to save the euro (Glöcker et al., 2016, Draghi 2012).

On the one hand, these functionalist spill-over dynamics contribute to explaining the rationale for BU. On the other hand, they do not shed light on the distinctive shape that BU took. This is where ideas and intergovernmental dynamics come into play. A constructivist approach to the making of BU would examine the ideas or policy paradigm underpinning BU to gauge whether an epistemic community was at work. Schaffer (2016) combines the 'constitutive and strategic role of ideas' to examine the making of $\mathrm{BU}$, arguing that 'ordo-liberal ideas' were constitutive for German 
preferences. At the same time, ideas were used as 'strategic resources by the German government's opponents in order to extract concessions from Germany' (Schaffer 2016: 962). In contrast, Matthijs (2016a) stresses the 'perverse logic' of German ordoliberalism in worsening the sovereign debt crisis, arguing that German policy-makers 'undercut their own stated goals' and made matters worse by sticking to ordo-liberal inspired policies, even in the light of clear evidence that these policies were not working.

Unlike in the construction of EMU, when stability-oriented ideas had considerable impact on the project design agreed, the debate on BU was shaped by competing policy paradigms concerning the causes of and solutions to the Euro Area sovereign debt crisis. Ordo-liberal or neoliberal economists and policy makers, principally based in creditor countries, argued that the crisis originated from the lack of fiscal consolidation in euro periphery member states, which had failed to take advantage of lower interest rates in EMU to consolidate their fiscal policies and undertake domestic structural reforms (Schmidt 2014). The key concern for these creditor country policy makers was to design a BU that avoided moral hazard (Dyson 2014), meaning perverse incentives that would increase the risk-taking behaviour by member states and their banks, should excessively generous support mechanisms with insufficient conditionality be included. The solution to the sovereign debt crisis was principally fiscal austerity accompanied by structural reforms in debtor countries, and Europeanlevel supervision of debtor country banks and limited conditional financial support for both sovereigns and their banks (Howarth and Quaglia 2016). 
A number of other, mainly Keynesian-inspired, economists (e.g., Paul Krugman) and policy makers in debtor countries were critical of low domestic demand in Germany, and the high level of its exports to other Euro Area member states (Dyson 2014). These economists and policy makers argued that the capital inflows prior to the crisis and outflows later were, at least in part, outside the control of the member states hit by the crisis, which in turn was worsened by the erratic behaviour of financial markets. Since (in their opinion) the problem was not the lack of fiscal discipline in the Euro Area periphery, they criticised the 'orthodoxy' of austerity, namely fiscal retrenchment accompanied by low or no growth (Blyth 2013; Schmidt 2014). The main solution for these economists and policy makers was to redress macroeconomic imbalances in the Euro Area - with efforts by both creditor and debtor member states - and provide financial support to debtor states (and banks in debtor states) through BU so as to stave off the worst of the crisis.

These competing policy paradigms shaped the intergovernmental negotiations on BU. Obviously though, it was not just a matter of ideas; competing interests were at stake. Creditor countries called for domestic austerity in debtor states combined with limited Euro Area financial support, which one way or another creditor countries would have to underwrite. Debtor states were keen to limit painful austerity measures domestically and called for Euro Area financial support. Indeed, the vast majority of research investigating the establishment of $\mathrm{BU}$ has adopted an intergovernmentalist approach which highlights material interests (Donnelly 2014, 2018; Fabbrini 2013; Howarth and Quaglia 2016; Schimmelfennig 2015; Schild 2018). 
Intergovernmental accounts of BU focus principally upon the competing preferences of Euro Area member states — normally, understood in terms of underlying macroeconomic interests — which had to be reconciled through EU negotiations. This reconciliation involved a number of convoluted compromises in the design of BU, most famously in the design of the SRM (Howarth and Quaglia 2016). Intergovernmentalist accounts have also considered the different bargaining power of the member states, generally focusing on the role and preferences of the main countries, notably Germany and, to a lesser extent, France. French policy-makers joined with the European Commission and debtor member states in the euro periphery - pushed for the construction of large-scale support mechanisms able to purchase debt directly from Euro Area member states and engage in bank recapitalisation. In return for support mechanisms, debtor member states were willing — in most cases with immense reluctance — to accept the supranationalisation of banking supervision (Howarth and Quaglia 2016). Thus, the interests of French and Southern European policy-makers in BU stemmed above all from a desire to establish a kind of financial backstop to the Euro Area via a lender-of-last-resort-style support for banks - in addition to ECB action — rather than governments.

German and a number of other creditor member state policy-makers sought to establish clear limits to their financial assistance for ailing banks and governments in countries hit by the sovereign debt crisis. They also made clear that the acceptance of joint liabilities for banks in the Euro Area should be preceded by the supranationalisation of banking supervision in order to ensure more effective control of banks in the euro periphery. These policy makers also sought a comprehensive assessment of large Euro Area banks to pre-date the operation of the SSM to 
determine which banks had so-called 'legacy problems' that precluded subsequent Euro Area support. German policy makers did not want to support ailing banks in the euro periphery with built up problems due to previous national regulation and supervision that they perceived to be inadequate (Schild 2018).

This intergovernmental debate on BU paralleled long-standing debates on Euro Area governance and the quest for solutions to the sovereign debt crisis. The French-led coalition, which included Southern European countries, sought support mechanisms, stressing the importance of 'solidarity'. The German-led coalition, which included Austria, the Netherlands and Finland, sought reinforced fiscal policy commitments (sustainable member state budgets), stressing the need to avoid 'moral hazard'.

The different preferences of the member states generated distributional conflicts that had to be reconciled through intergovernmental bargaining. The outcomes of the negotiations were the result of compromises between the interests and ideas of different member states, but were often closer to the preferences of the most powerful player, Germany which had a 'constrained veto power' (Bulmer and Paterson 2013; Bulmer 2014). Its power resulted from the size and relative stability of its economy and its banking system. This power was however constrained because Germany had a clear economic and political interest in avoiding major disruptions to EMU and the collapse of the Euro Area. In fact, even in its 'light' version, BU implied forms of limited fiscal solidarity, which in the end Germany came to accept.

Domestic political economy differences reflected in national banking systems also directed member state preferences on the elements of BU. Germany with its non- 
concentrated and diverse banking system containing a large number of smaller public law (alternative) banks sought to limit ECB supervision to only the largest entities. Germany, with banking groups supported by well-funded joint liability schemes also sought to limit the potential reach of the SRM and opposed the creation of the EDIS which — according to Commission proposals - would call upon German bank funds to supply a European mechanism (Howarth and Quaglia 2016). German policy makers feared that German banks would end up having to pay off the depositors and bond holders of Italian (etc.) banks given the inadequate funding of Italian (etc.) deposit and resolution schemes. France, with its more concentrated banking sector, opposed uneven ECB supervision and sought 'indirect' ECB supervision via national authorities. France, with its underfunded bank deposit guarantee scheme, supported the EDIS.

To sum up, as with the establishment of EMU, several theoretical approaches can be deployed and combined to explain the move to and design of BU. Indeed, several accounts have sought to combine various approaches. For example, some authors (Börzel and Risse 2018; Quaglia and Spendzharova 2017) have combined liberal intergovernmentalism and neofunctionalism, in order to account for the move to BU. Jones et al. (2016) have used a two-step approach, arguing that negative spill-overs from previous incomplete integration in EMU triggered the sovereign debt crisis. This was followed by intergovernmental negotiations, which paved the way for the establishment of BU. 
We build on these works, arguing that an incomplete EMU generated spill-overs that provided the rationale to propose $\mathrm{BU}$. As opposed to the negotiations leading to the EMU project, the European Commission played only a limited role (Hodson 2013). Rather, the ECB can be seen as the important supranational policy entrepreneur that pushed most actively for BU. There were competing paradigms at work in the negotiations and the design of BU. These competing ideas were often aligned with different economic interests of the member states, which in turn reflected different national banking systems.

\section{Theoretical lessons from EMU and BU}

There are three main theoretical lessons from this comparison of the making of EMU and BU. First, there are obvious parallels between the neofunctionalist dynamics leading to both projects. Spill-over, to be understood in terms of the Mundell-Fleming trilemma and Padoa-Schioppa's more problematic 'inconsistent quartet', generated pressures in favour of establishing EMU. Similarly, once an incomplete EMU was established, Schoenmaker's financial trilemma generated spill-over pressure to complete EMU by establishing BU. The move to both BU and EMU can also be interpreted through the lens of the so-called 'bicycle theory' of European integration, whereby the EU has to move forward in order not to fall apart because of intensifying economic and political pressures created by existing institutional and policy frameworks (see also Jones et al. 2016). This meant tackling the economically and politically problematic asymmetry of the EMS and, more recently, the sovereign debt crisis and EMU asymmetry. The move to BU did not fundamentally address the causes of the crisis, but its intensity was possibly diminished. In order to lower the risk of financial instability and reverse the fragmentation of the Single Market in 
finance, Euro Area policy-makers moved to promote the completion of EMU by establishing BU, transferring banking supervision and resolution (only in part) to the Euro Area level. These spill-over dynamics and path-dependence created by monetary integration in the 1980s, in the one case, and the 2000s, in the other, were exploited by supranational policy entrepreneurs, respectively the Commission and the ECB.

The second theoretical lesson to draw from this comparison of the move to EMU and BU is the ongoing importance of the member states, their interests, and their relative bargaining power. Although spill-over pressures for EMU and BU are undeniable, the agreements on their establishment and design were very much driven by intergovernmental dynamics. There are clear parallels in the intergovernmentalism of EMU and BU. The former was promoted by follower countries as a way to move beyond Germany's hegemonic position in the ERM of the EMS. German policymakers, who had a strong bargaining position and worried about the moral hazard created by a single currency and monetary policy largely dictated the design of EMU: a full Monetary Union centred on a powerful independent central bank, with a very limited form of Economic Union focused principally on a restrictive understanding of sustainable fiscal policy.

As with the making of EMU, a version of BU — one that emphasised support mechanisms - was promoted by France and Euro Area member states hit hardest by the sovereign debt crisis as a way to tackle the crisis and boost confidence in international financial markets. German policy on the elements of BU was directed by moral hazard concerns and Germany was in a stronger bargaining position because it was considerably less affected by the sovereign debt crisis, despite the exposure of 
some German banks to Southern Europe. Germany was however indirectly affected by the crisis, which threatened the very survival of the euro. For this reason, German policy-makers reluctantly agreed to BU. However, as with EMU, they were able to impose most of the BU design: on the SSM - no ECB direct supervision of small banks - the SRM — national veto on the mutualisation of resolution funds - the absence of an EDIS (to date) and a limited fiscal backstop subject to tight conditionality. This asymmetric configuration of BU caused asymmetric effects across and within the member states, and partly explains why the sovereign debt crisis simmers and a future crisis looms.

The third theoretical lesson to draw is that on BU as with EMU there were competing policy paradigms at stake in intergovernmental debates over design. These ideas were often in line with the domestic political economy concerns of the national policy makers who proposed them. The main pre-occupation of stability-oriented countries was to establish a system that would limit moral hazard. Consequently, German negotiators insisted upon inserting 'no bail-out' and 'no monetary financing' clauses into the Maastricht Treaty (Dyson and Featherstone 1999). They opposed any step towards fiscal federalism or 'transfer union', fearing that Germany would end up becoming the main contributor, as it always had been in total net terms to the EU budget. German policy-makers also successfully demanded convergence criteria that countries had to meet in order to be able to join EMU and then, in 1994, proposed the SGP, the objective of which was to avoid excessively loose national fiscal policies in EMU (Heipertz and Verdun 2010). 
To diminish the likelihood of moral hazard, creditor countries (notably, Germany) sought to establish clear limits to their financial assistance to ailing banks and debtor member state governments hit by the sovereign debt crisis - this accounts for the limited scope of the SRM, the failure to agree the EDIS (to date), and the limited amount of ESM funds and their conditional use. By contrast, France and debtor states were keen to ease the impact of austerity and set in place mechanisms for financial solidarity or burden sharing in the Euro Area. The parallel with current debates on the creation of a Euro Area budget is great. Germany and other creditor member states have been reluctant to allow the creation of anything beyond a small Euro Area budget funded through the main EU budget and they insist upon heavy conditionality attached to any financial support provided. France and the euro periphery member states call for the creation of a large Euro Area budget separate from the EU budget as an essential move to decrease uneven adjustment costs linked to EMU asymmetry and ensure the survival of the Euro Area. Plus ça change.

\section{Conclusion}

The agreement on BU can be seen as a response to the asymmetric design of EMU a Monetary Union with a limited form of Economic Union - and to the fragmentation of the Single Market in financial services. BU was also a crisis-driven attempt to address several important issues that were sidestepped or papered over during the negotiations leading to the Maastricht Treaty — principally the allocation of supervisory responsibilities to the ECB and the creation of a fiscal backstop for the Euro Area. Other closely related issues - notably, the reinforcement of the single rule book on banking and the harmonization of national deposit guarantee schemes stemmed from the incomplete nature of the Single Market in financial services. The 
Franco-German debates on BU paralleled longstanding debates on Euro Area governance and solutions to the sovereign debt crisis. The French sought support mechanisms; the Germans demanded reinforced rules and rule-following.

Neofunctionalism is a useful theoretical framework to understand the dynamics created by functional and cultivated spill-over — that encouraged member state governments to consider and then accept the move to both EMU and BU. Without these dynamics neither project would have been adopted. Intergovernmentalism is more helpful to explain the design of the EMU and BU projects agreed by member state governments. German preferences largely, but not entirely, explain the asymmetric design of the two projects - more on Monetary Union and less on Economic (fiscal) Union, more on the SSM and less on the other elements of BU.

In the intergovernmental negotiations leading to both EMU and BU, Germany possessed a 'constrained veto power', which involved having to accept significant compromises in order to meet other political and macro-economic goals. Liberal intergovernmentalism points to the importance of microeconomic interests - large exporters and banks respectively — and the need to consider domestic political economy concerns to understand German and French preferences on EMU and BU. Constructivism attracts our attention to the importance of ordo-liberal ideas - a preoccupation with both price stability and moral hazard - that drove German policies and largely shaped the institutional design of both projects. The spread of these ideas to other member states - more in the case of EMU than with BU - made compromises with France and debtor / euro periphery member states possible, resulting in asymmetric versions of both EMU and BU. 


\section{References}

Blyth, M. 2013. Austerity: The History of a Dangerous Idea, Oxford: OUP.

Boerzel, T., and T. Risse. 2018. 'From the Euro to the Schengen crises: European integration theories, politicization, and identity politics', Journal of European Public Policy 25 (1): 83-108.

Bulmer, S. 2014. 'Germany and the Eurozone Crisis: Between Hegemony and Domestic Politics', West European Politics, 37 (6): 1244-1263.

Bulmer, S., and W. Paterson. 2013. 'Germany as the EU's Reluctant Hegemon? Of Economic Strength and Political Constraints', Journal of European Public Policy, 20 (10): 1387-1405.

Carstensen, M., and V. Schmidt. 2018. 'Power and changing modes of governance in the Euro crisis', Governance, DOI: 10.1111/gove.12318

Chang, M. 2018. 'The Creeping Competence of the European Central Bank During the Euro Crisis', Credit and Capital Markets - Kredit und Kapital, 51 (1): 41-53.

De Grauwe, P., ed. 1990. The European Monetary System in the 1990s, London/New York: Longman

De Rynck, S. 2015. 'Banking on a Union: The politics of changing Eurozone banking supervision', Journal of European Public Policy, 23 (1): 119-135.

Donnelly, S. 2014. 'Power politics and the undersupply of financial stability in Europe', Review of International Political Economy, 21 (4): 980-1005.

Donnelly, S. 2018. Power Politics, Banking Union and EMU: Adjusting Europe to Germany, Abingdon: Routledge. 
Draghi, M. 2012. 'Verbatim of the remarks made by Mario Draghi', ECB, Frankfurt, 26 July; available at:

https://www.ecb.europa.eu/press/key/date/2012/html/sp120726.en.html

Dyson K. 1994. Elusive Union: The Process of Economic and Monetary Union in Europe, London: Longman.

Dyson K. 2000. The Politics of the Eurozone, Oxford: Oxford University Press

Dyson, K. 2014. States, Debt and Power: 'Saints' and 'Sinners', Oxford: Oxford University Press.

Dyson, K., and K. Featherstone. 1999. The Road to Maastricht, Oxford: Oxford University Press.

Epstein, R., and M. Rhodes. 2016. 'The Political Dynamics behind Europe's New Banking Union', West European Politics 39 (30): 415-37.

European Commission. 1990. One Market, One Money, Brussels.

European Central Bank (ECB). 2012. 'Introductory Statement', Presented by Mario Draghi, and Vítor Constâncio, , ECB, Frankfurt, 6 December; available at: «http://www.ecb.int/press/pressconf/2012/html/is 121206.en.html».

European Central Bank (ECB). 2011. 'The ECB's non-standard measures: impact and phasing-out', ECB Monthly Bulletin, July: 55-69.

Fabbrini, S. 2013. 'Intergovernmentalism and Its Limits: Assessing the European Union's Answer to the Euro Crisis', Comparative Political Studies, 46 (9): 1003 1029.

Frieden, J. 1996. 'The Impact of Goods and Capital Market Integration on European Monetary Politics', Comparative Political Studies, 29 (2): 193-222.

Giavazzi, F., S. Micossi, and M. Miller, M. 1989. The European Monetary System, Cambridge: Cambridge University Press.

Glöckler, G., J. Lindner, and M. Salines. 2016. 'Explaining the Sudden Creation of a Banking Supervisor for the Euro Area', Journal of European Public Policy, 24 (8): $1135-1153$.

Hall, P. 2014. 'Varieties of Capitalism and the Euro Crisis', West European Politics, 37 (6): 1223-1243.

Heipertz, M., and A. Verdun. 2010. Ruling Europe: The politics of the stability and growth pact, Cambridge: CUP.

Hodson, D. 2009. 'EMU and political union: what, if anything, have we learned from the euro's first decade?', Journal of European Public Policy, 16 (4): 508-526. 
Hodson, D. 2013. 'The Little Engine that Wouldn't: Supranational Entrepreneurship and the Barroso Commission', Journal of European Integration, 35 (3): 301-314.

Howarth, D. 2001. The French Road to European Monetary Union, Palgrave: London.

Howarth, D., and P. Loedel. 2005. The European Central Bank: The New European Leviathan?, Basingstoke: Palgrave Macmillan.

Howarth, D., and L. Quaglia. (2015) 'The Political Economy of the euro area's Sovereign Debt Crisis', Review of International Political Economy, 22 (3): 457-484.

Howarth, D., and L. Quaglia. (2016) The Political Economy of European Banking Union, Oxford: Oxford University Press.

Kaltenthaler, K. 1998. Germany and the Politics of Europe's Money, Durham: Duke University.

Jabko, N. 1999. In the name of the Market: how the European Commission paved the way for monetary union', Journal of European Public Policy, 6 (3): 475-495.

Jones, E., D. Kelemen, and S. Meunier. 2016. 'Failing Forward? The Euro Crisis and the Incomplete Nature of European Integration', Comparative Political Studies 49 (7): 1010-1034.

Loedel, P. 1999. Deutsche Mark Politics: Germany in the European Monetary System, Boulder: Lynne Rienner.

McNamara, K. 1998. The Currency of Ideas: Monetary Politics in the European Union, Ithaca: Cornell University Press.

Marcussen, M. 2000. Ideas and Elites, Aalborg: Aalborg University.

Matthijs, M. 2016. 'The Euro's “Winner-Take-All” Political Economy: Institutional Choices, Policy Drift, and Diverging Patterns of Inequality', Politics \& Society, 44 (3): 393-422.

Matthijs, M. 2016. 'Powerful rules governing the euro: the perverse logic of German ideas', Journal of European Public Policy, 23 (3): 375-391.

Moravcsik, A. 1998. The Choice For Europe, London: University College London Press.

Nielsen, B., and S. Smeets. 2018 'The role of the EU institutions in establishing the banking union. Collaborative leadership in the EMU reform process', Journal of European Public Policy, 25 (9): 1233-1256.

Oatley, T. 1997. Monetary Politics: Exchange Rate Cooperation in the European Union, Ann Arbor: University of Michigan Press. 
Padoa-Schioppa, T. 1982. 'Capital Mobility: Why is the Treaty Not Implemented?', in Padoa-Schioppa, T. 1994. The Road to Monetary Union in Europe, Oxford: Clarendon Press.

Quaglia, L., and A. Spendzharova. 2017. 'The Conundrum of Solving "Too Big to Fail" in the European Union: Supranationalization at Different Speeds', JCMS: Journal of Common Market Studies, 55 (5): 1110-1126.

Sadeh, T., and A. Verdun. 2009. 'Explaining Europe's Monetary Union: A Survey of the Literature', International Studies Review, 11 (2): 277-301.

Sandholtz, W. 1993. 'Choosing Union: Monetary Politics and Maastricht', International Organisation, 47 (1): 1-39.

Schaffer, D. 2016. 'A Banking Union of Ideas? The Impact of Ordoliberalism and the Vicious Circle on the EU Banking Union', JCMS: Journal of Common Market Studies, 54 (4): 961-980.

Schild, J. 2018. 'Germany and France at Cross Purposes: the Case of Banking Union', Journal of Economic Policy Reform, 21 (2): 102-117.

Schmidt, V.A. 2014. 'Speaking to the Markets or to the People? A Discursive Institutionalist Analysis of the EU's Sovereign Debt Crisis', British Journal of Politics \& International Relations, 16 (1): 188-209.

Schoenmaker, D. 2013. Governance of International Banking: The Financial Trilemma, Oxford, Oxford University Press.

Schimmelfennig, F. 2016. 'A differentiated leap forward: spillover, path-dependency, and graded membership in European banking regulation', West European Politics, 39 (3): 483-502.

Schimmelfennig, F. 2015. 'Liberal Intergovernmentalism and the Euro Area Crisis', Journal of European Public Policy, 22 (2): 177-95.

Verdun, A. 1999. 'The Role of the Delors Committee in the Creation of EMU: an Epistemic Community?', Journal of European Public Policy, 6 (2): 309-328.

Verdun, A., ed. 2002. The Euro: European integration theory and economic and monetary union, Lanham, Md.: Rowman \& Littlefield Publishers.

Verdun, A. 2015. 'A historical institutionalist explanation of the EU's responses to the euro area financial crisis', Journal of European Public Policy, 22 (2): 219-237.

Verdun, A. 2017. 'Political leadership of the European Central Bank', Journal of European Integration, 39 (2): 207-221.

Walsh, J. 2000. European Monetary Integration and Domestic Politics. Britain, France and Italy, London: Lynne Rienner. 
